\title{
Brazil, USA, and Germany: A comparison of legislation in the fight against COVID-
}

\section{9}

\author{
Brasil, EUA e Alemanha: Uma comparação da legislação no enfrentamento à COVID-19 \\ Brasil, Estados Unidos y Alemania: Una comparativa de legislación en la lucha contra el COVID-19
}

Received: 01/13/2021 | Reviewed: 01/15/2021 | Accept: 01/19/2021 | Published: 01/24/2021

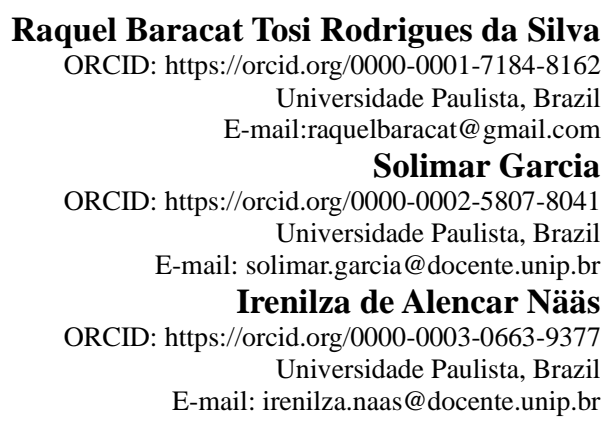

\begin{abstract}
This article compares Brazil, the United States, and Germany's laws in the face of the COVID-19 pandemic, describing the scenario of these laws, comparing them to evaluate which country had the best performance, in their laws concerning the COVID-19, in the face of the international requirements. The primary laws of Brazil, the USA, and Germany were used, comparing WHO requirements and international requirements, analyzing: speed in the isolation decision; assembly of hospitals and equipment; economic measures for the population; organization of states and international negotiation. The comparison system established was based on scores (scores), with scores ranging from 1 to 5 (very poor to very good) depending on the existence of legislation for each country (Brazil, USA, and Germany), for each type of requirement, concerning the level of awareness of the norm's applicator to the problems faced in the pandemic. Although some nations have acted quickly in imposing restrictions and recommending social isolation, they have been hampered by economic, social, and political factors.
\end{abstract}

Keywords: World Health Organization; Legal standards; Scores; Compared laws; COVID-19.

\section{Resumo}

Este artigo compara legislações do Brasil, Estados Unidos e Alemanha frente à pandemia de COVID-19, descrevendo o cenário dessas leis, comparando-as com o intuito de avaliar qual país teve melhor desempenho, em suas legislações frente à COVID-19, diante das exigências internacionais. Foram utilizadas as principais legislações do Brasil, EUA e Alemanha, comparando as exigências da OMS e exigências internacionais, sob os seguintes aspectos: rapidez na decisão de isolamento; montagem de hospitais e equipamentos; medidas econômicas para população; organização dos estados e negociação internacional. O sistema de comparação estabelecido foi baseado em escores (notas), sendo aplicadas notas de 1 a 5 (muito ruim a muito bom) em função da existência de legislações para cada país (Brasil, EUA e Alemanha), para cada tipo de exigência, relativas ao nível de consciência do aplicador da norma aos problemas enfrentados na pandemia. Embora algumas nações tenham agido rapidamente ao impor restrições e recomendar o isolamento social, elas foram prejudicadas por fatores econômicos, sociais e políticos.

Palavras-chave: Organização Mundial de Saúde; Padrões legais; Pontuações; Leis comparadas; COVID-19.

\section{Resumen}

Este artículo compara las leyes de Brasil, Estados Unidos y Alemania ante la pandemia del COVID-19, describiendo el escenario de estas leyes, comparándolas con el objetivo de evaluar qué país tuvo el mejor desempeño, en sus leyes en relación con el COVID-19, a frente de los requisitos internacionales. Se utilizaron las principales leyes de Brasil, EE. UU. y Alemania, comparando los requisitos de la OMS y los requisitos internacionales, analizando: rapidez en la decisión de aislamiento; montaje de hospitales y equipos; medidas económicas para la población; organización de estados y negociación internacional. El sistema de comparación establecido se basó en puntajes (puntajes), con puntajes que van del 1 al 5 (muy pobre a muy bueno) dependiendo de la existencia de legislación para cada país (Brasil, EE. UU. Y Alemania), para cada tipo de requisito, sobre el nivel de conocimiento del aplicador de la norma sobre los problemas que enfrenta la pandemia. Aunque algunas naciones han actuado rápidamente al imponer 
restricciones y recomendar el aislamiento social, se han visto obstaculizadas por factores económicos, sociales y políticos.

Palabras clave: Organización Mundial de la Salud; Estándares legales; Puntuaciones; Leyes comparadas; COVID-19.

\section{Introduction}

In November 2002, a severe acute respiratory syndrome (SARS) emerged in China, causing global anxiety as the outbreak spread rapidly and, in July 2003, resulted in more than 8,000 cases in 26 countries. In December 2019, a new Coronavirus, called SARSCoV2, emerged in Wuhan, China, and led to an outbreak of disease that spread quickly. On January 30, 2020, COVID19 was declared a public health emergency of international interest. In the absence of vaccines and specific treatment, the only public health tools available to control communicable diseases from person to person are measures of isolation and quarantine, social distance, and restraint from the community (Cheng et al., 2004). In Brazil, as in other countries, activities that cause crowds of people such as classes and all kinds of shows, sports or artistic, and work in industrial facilities were stopped, interrupting the provision of services to thousands of workers (the USA, 2020).

In February 2020, quickly passing through the Brazilian Congress, law No. 13,979 / 2020 (Brazil, 2020) was approved, which deals with measures to deal with the pandemic caused by the coronavirus responsible for the 2019 outbreak. Social isolation, without unanimity among the state governments and even without the President of the Republic's adherence, in Brazil, the criteria adopted to reduce the impact of the coronavirus are far below what was announced by other countries face the crisis (FGV, 2020).

The figures on COVID-19 have increased since it was discovered and characterized as a pandemic by the World Health Organization (WHO), with $80 \%$ of patients showing mild and uncomplicated symptoms, $15 \%$ were hospitalized with the need for oxygen therapy, and 5\% needed to be seen in an intensive care unit (ICU) (WHO, 2019). Health systems would have a high saturation of health systems with the increase in beds and lack of space in hospitals if there is no containment of the virus and one of the main conclusions is that if actions to expand the supply of beds or containment of the virus (Sarkar \& Chakrabarti, 2020; IHME COVID-19, 2020; Zhang et al., 2020; Waldman et al., 2020; Moghadas et al., 2020; Verhagen et al., 2020; Walker et al., 2020). Demand for hospitalizations among COVID-19 patients is influenced by different factors, such as age and conditions, with different effects in societies in which the pandemic is advancing.

In Brazil, studies developed by Castro et al. (2020) and Rache et al. (2020) estimate the collapse of both the regional and national health systems between March and April 2020. The supply estimates were performed, considering only the beds of the Unified Health System (SUS). In the studies, demographic factors were not taken into account in regional cases, in August and September when there was a drop in the use of ICU, corresponding to a decline in contamination due to the rules of isolation and use of masks in public places (Rache et al., 2020; Batista et al., 2020; Noronha et al., 2020).

The economic problem and the lack of income of people unable to work were the problems faced worldwide. The Brazilian government announced the payment of $\mathrm{R} \$ 600.00$ for three months, at first. After the program extends until December 2020, for workers without income and informal, anticipating the 13th salary of INSS pensioners and retirees, expansion of the Bolsa Família program, there was a temporary reduction of taxes for companies, sending of funds to the Ministry of Health and transfers to States and municipalities, which reach 4\% of the country's Gross Domestic Product (GDP). (FGV, 2020). In Germany, spending reached about R \$ 4.4 trillion, or 37\% of GDP (Gordon, 2019). Spain and the United Kingdom even involved 17\% of GDP in dealing with the crisis, data referring to the first half of 2020 (FGV, 2020). The British government has announced aids of up to $80 \%$ of the income of workers who have their salaries suspended, respecting the limit of 2,500 pounds (about R \$14,800) per month, higher than the median English income. In the United States of America (USA), the coronavirus's reality has rekindled the political debate about workers' right to leave work to take care of their health 
or that of their families. The US has already involved $6.3 \%$ of GDP in actions to mitigate the crisis and may reach $11.3 \%$ if other measures are approved at the congress, data for the first half of 2020 (Whittle \& Hailwood, 2020).

Following World Health Organization rules would be essential criteria for countries when facing global health crises. The discussion about whether countries 'responses are more or less adequate to address the pandemic will extend over historical time and what can be predicted is that countries' efforts are more or less proportional to the sizes of their economies. Legal frameworks play a vital role in supporting public health responses to infectious diseases, and a strong government is critical to effective pandemic management.

In this scenario of different government actions to combat the pandemic concerning workers and the population in general, this study aimed to compare the actions of the governments of three countries (Brazil, Germany, and the USA) against the norms proposed by the World Health Organization in facing the 2019 and 2020 health crisis caused by the new coronavirus, to mitigate the problems arising from the pandemic.

\section{Background}

\subsection{Brazilian legislation}

Law 13,979 / 2020 provides normative items that can be used by health authorities to contain the progress of the disease. The following stand out quarantine and isolation, the separation of people, already infected (and luggage, means of transport, correspondence, etc.), to avoid the spread of the virus. Quarantine refers to people who have not yet contracted the virus, in addition to restricting activities. With the reduction of people in environments to its minimum, there was the preservation of public health and without a definite deadline for closing this rule, despite the second paragraph of article 1 of Law 13,979 stating that an act of the Minister of State for Health will provide on the duration of the public health emergency (Brazil, 2020).

Despite individual rights and guarantees, the Constitution also establishes that health is a right of all and a duty of the State and that it must guarantee public policies to reduce risks to people's health. In this case, two constitutional rights are involved, which is the right to health and freedom. The controversy about the inclusion of norms was regarding the guarantee of individual rights and the adoption of quarantine measures. Such crisis decisions usually impose severe legal challenges. In this scenario, the collectivity's interest prevails, who establishes and takes care of the collectivity right is the State, which has this duty. Therefore, no matter how much the person claims the right to individuality, the State must provide and provide security to the community in this scenario.

The Penal Code, in article 132, presents the danger to life and health. The penalty is from three months to one year for anyone who exposes the life or health of another indirect or imminent danger. In addition to being in the Constitution, the Penal Code also establishes penalties for people who come to endanger others' lives or when the State establishes a protocol that must be followed by all (Criminal law, 2019). The new Brazilian law on the coronavirus provides that people must be subject to compliance with the measures provided for, so that failure to comply with them will result in liability under the law's terms. According to paragraph 7 of article 3 of the new diploma, isolation and quarantine can be taken not only by the Minister of Health but also by local managers, provided they are authorized by the Ministry (Brazil, 2020). This standard provides for the possibility of compulsory examinations, laboratory tests, collection of clinical samples, vaccination, and other prophylactic measures. Such measures do not need the scrutiny of the Ministry of Health. Exhumation, necropsy, cremation, and handling of cadavers can also be determined by local authorities, provided the minister, such as quarantine, authorize them.

\subsection{USA Legislation}

When Roosevelt enacted the Federal Labor Law of the USA in the 1930s, the law provides that no right could be 
established for the worker to leave work due to health problems, the stability of the disabled employee, illness, or accident. The law also provides that the worker cannot work due to illness or accident. He loses his income and may have his contract terminated.

Unfortunately, American labor law places the country below the best statistics from countries regarding social protection for workers (and even about much less developed countries, such as Brazil). In 1993, during the Bill Clinton administration, the Family and Medical Leave Act was approved, the right to leave work without pay for a maximum of twelve weeks over one year was established in the following cases: serious illness, birth or adoption of a child and necessary care for a direct dependent with severe illness or disability. This law was ineffective since the leave is unpaid and limited to a maximum period, regardless of the leave's medical condition. The law covers only workers from companies with more than fifty employees; the license right can only be requested by employees who have at least one year of service. To apply for a license, one must have worked a minimum of 1250 hours in the last twelve months (which practically precludes the right for part-time workers). Just severe illnesses are considered the cause of dismissal, which makes the right subjective and creates tensions between boss and employee; there is no guarantee of employment for the employee returning from leave (although retaliatory dismissals may be questioned in court against the discrimination argument). These rules apply to workers in the private sector and public servants, although they generally manage to negotiate more favorable conditions in collective bargaining with the public administration (Gordon, 2019).

Due to the numerous restrictions of the Family and Medical Leave Act, studies by the US Department of Labor indicate that less than $50 \%$ of US workers in the private sector qualify as eligible to request removal for health reasons. This has more damaging consequences for the American legal system, which is that it ends up encouraging many employees to work sick, either because the leave is unpaid or because they are only considered serious diseases for removal (the USA, 2020). So, for example, it is common for employees with very strong but not incapacitating flu (which would require a day or two of rest) to end up going to work, with the risk of contamination to their colleagues, in times of COVID-19 pandemic causes a threat of severe contamination to public health (National, 2020).

Thus, the Coronavirus crisis exposes one of the central contradictions and injustices in the US labor legal system. Employees can be prevented from working not only because of a condition of personal disability but also becau se of a public health issue arising from mandatory quarantine. Furthermore, even in this situation, they will not receive their wages for the period of absence (the USA, 2020). The pandemic scenario is difficult for American employees with an employment contract (protected or not by the Family and Medical Leave Act) and still disastrous for workers in the so-called "gig economy," who have no social protection and are at risk of being contaminated and contaminating customers, especially those who work through applications such as drivers and delivery people, whose activities put them in direct contact with dozens of people a day (NHI, 2020).

Another issue with the American laws is the health plans that make Americans worried about the high cost related to the coronavirus and its impact on the family budget. The country's press reported some suspicious cases or had to be in isolation and received high bills from health services and the population's difficulty accessing health care for financial reasons. Diagnostic care, quarantine, and coronavirus treatment can be budgetary, and it is estimated that a day of treatment at a hospital in the US costs \$4,293, compared to \$1,308 in Australia and \$ 481 in Spain. Hospital admissions can be costly for patients without health insurance or those who pay co-participation (National, 2020).

\subsection{Germany Legislation}

German law protects against infectious diseases and can be found in the Infection Protection Act (Infektionsschutzgesetz, IfSG) and allows competent authorities to take different measures to prevent and control infectious 
diseases. The law distinguishes between monitoring ( $\S \S 6$ and following, IFS), preventive measures ( $\S 116$ and following, IFS), and measures to combat infectious diseases ( $\S 24$ and following, IfSG) (Act of Mitigate, 2020). Measures can be taken about sick people, suspected illnesses or infections, or people who excrete pathogens without showing symptoms. Some measures can also be taken against the general public. This law also expressly provides that quarantines at home or in select medical isolation units may be ordered ( $\$ 30$ IfSG), a ban on professional activity ( $\$ 31$ IfSG), or childcare facilities may be closed ( $\$ 33$ IfSG). According to $§ 28$ I S. 2 IfSG, the competent authority can also restrict or prohibit events or other meetings of many people. Also, § 28 I S. 1 IfSG contains a general clause according to which the authority can take all necessary measures. Measures under the Infection Protection Act can be ordered against individuals through an administrative act (Verwaltungsakt) and administrative regulations (Rechtsverordnungen) addressed to the general public ministers of health. Competent authorities can issue "general administrative acts" (Allgemeinverfügung), for example, to prohibit mass events (§ 28 Is. 2 IfSG). (Act of Mitigate, 2020). Until recently, Germany focused on quarantine orders for people who had contact with infected people or in high-risk regions. In the meantime, everyone is prohibited from holding mass events (initially with more than 1,000, and later with 100 or even fewer participants).

Universities stopped teaching in the classroom, and the start of the summer lecture period was postponed. More and more cities are closing stores (in addition to supermarkets and pharmacies), leisure and sports facilities, restaurants and bars or, at least, introducing special distance regulations for food companies. This was a more cautious way than American countries like Brazil and the United States (Act of Mitigate, 2020). The Federal government and the ministers reached an agreement on the implementation of the measures mentioned above, which are implemented uniformly throughout Germany by the competent authorities and also, there is a Joint Situation Center of the Federal government, which is also the focal point national authority for communication with the World Health Organization, following art. 4 of the International Health Regulations. (European, 2020). The Robert-Koch-Institute is a Federal institution that reports to the Federal Ministry of Health and provides competent authorities at the state level with technical information and issuing recommendations in significant epidemiology cases. In this Institute, a Preparation Plan is also issued for pandemic and recently added recommendations for the current Coronavirus pandemic (RKI, 2020).

Medical insurance companies generally bear medical treatment costs in Germany, and German employees are entitled to continuous compensation in the event of illness, following $\S 3$ of the Continued Remuneration Act (European, 2020). There is no general right to have a registered office in Germany, but German companies tend to accept it whenever possible. The Civil Code (Bürgerliches Gesetzbuch) provides that employees who are prevented from providing services for a relatively trivial period for a reason in their person without fault on their part are entitled to full remuneration. After the Coronavirus pandemic, conditions for compensation for short-term work will be relaxed by the law on temporary improvement related to the crisis of regulations for short-term compensation. (Act of Mitigate, 2020). However, according to the Federal Minister of Finance, 20 billion euros have been transferred to the National Bank KfW (Kreditanstalt für Wiederaufbau) to finance unlimited loans for companies, and several states provide superior financial support for companies. There is also a special compensation fund for freelancers and people involved in the cultural sector who suffer financial losses due to the crisis of the crown, i.e., Germany has better support for cases of catastrophes and pandemic to its population, both in health and the economy (Act of Mitigate, 2020; European, 2020).

\section{Methodology}

The present study is an exploratory research with a qualitative and quantitative approach (Pereira et al., 2018), which reports the response of actions in the confrontation of the COVID-19 pandemic. Economic conditions were initially raised through economic and development indexes (human development index, HDI; population density (hab / km2), DP; and Gross 
National Income, RND) and other indexes (Doctors per inhabitant, MD; average time in school (year), TE; and Life expectancy (year), EV) in the three countries studied to elaborate a qualitative scenario of the studied nations (UNDP, 2019). RND is a measure of a country's income. It includes all income earned by residents and businesses in a country, including any income earned abroad.

Then, the Brazilian health laws of the United States and Germany on pandemics were described: Federal Constitution (Brazil, 1999), Brazil (2020), CDC (2020), and Germany (European, 2020 and Act of Mitigate, 2020). The above legislations were compared, scores were issued, and their contents were analyzed. The scores were classified on a scale of 1 to 5 (scale adapted from Likert), denoting the opinion of the norm of the country in question regarding the issues raised by the WHO adapted and compared to what Brazil, USA, and Germany have in their legislation (Table 1), which shows the evaluation by the score.

The definition of very bad (score $=1$ ) is that it has few or nonexistent standards that address the requirements, while the definition of very good (score $=5$ ) corresponds to the situation in which some rules regulate those situations. The intermediate situations were stipulated in the range 1 to 5 , with corresponding definitions. The alternative solutions and requirements were grouped by consensus and disparities and scored with a score of 1 to 5 . From then on, the result will be the result of the standards in these two countries, which is below what the population has about the pandemic and that studies on pandemic prove to be correct.

Table 1. Correspondence of the score value with the assessment.

\begin{tabular}{cc}
\hline Score & Evaluation \\
\hline 1 & Very poor \\
2 & Poor \\
3 & Medium \\
4 & Good \\
5 & Very good \\
\hline
\end{tabular}

Source: Authors.

The primary laws of Brazil, the USA, and Germany on pandemic cases were used and compared to WHO requirements and international requirements, of which the following points were analyzed:

1. Speed in the decision of social isolation;

2. Setting up hospitals and equipment to serve the population;

3. Economic measures for the survival of some workers;

4. Organization of states to face the pandemic;

5. International organization to face the pandemic.

The scores were obtained by studying data retrieved from legislation in Brazil, Germany, and the United States and through the studied literature and bibliography. Based on the scores' application, the texts and content of legislation and decision-making between Brazil, the United States, and Germany were evaluated in the face of the COVID-19 pandemic. We used WHO measures and asked whether countries are prepared for a pandemic situation. and how to solve this problem with rules and legislation. 


\section{Results and Discussion}

Pandemics rarely affect everyone uniformly. Black Death, for example, in the 14th century, reduced the global population by a third, with the highest number of deaths observed among the most impoverished populations. Densely populated by malnourished and overworked peasants, medieval Europe was a breeding ground for bubonic plague. Seven centuries later, with a global gross domestic product of almost \$ 100 trillion, the world did not have the resources to prevent another pandemic (Hoadley et al., 2020).

Poor populations who do not have access to health services under normal circumstances are left more vulnerable in crisis times. Misinformation and lack of communication disproportionately affect individuals with less access to information channels, who are therefore more likely to ignore government health warnings. With the introduction of physical distance measures, home Internet coverage must be ubiquitous (Roser, 2020).

\subsection{Comparison of the economic data of the countries studied}

In this work, Brazil, the USA, and Germany's primary laws for pandemic cases were studied compared to the WHO requirements, from the items on the speed of decision; assembly of hospitals and equipment to serve the population. Economic measures for the survival of some workers and the organization to face the pandemic, scores were applied by applying higher scores to the country with the best structure in each item or lower score to the country with a deficiency in a particular item compared standard. Table 2 shows the comparison of economic indices between the countries studied.

Table 2. Economic, medical rates per inhabitant, population density, average schooling time, and life expectancy.

\begin{tabular}{ccccccc}
\hline Country & HDI & $\begin{array}{c}\text { PD } \\
\left(\mathbf{h a b} / \mathbf{k m}^{\mathbf{2}}\right)\end{array}$ & TNI & $\begin{array}{c}\text { DI } \\
\text { (doctor/10 } \\
\text { hab.) }\end{array}$ & TS (year) & LE (year) \\
\hline Brazil & 0.761 & 25.25 & 14,068 & 2 & 7.8 & 75.7 \\
USA & 0.920 & 35.97 & 56,140 & 3 & 13.4 & 78.9 \\
Germany & 0.939 & 239.61 & 46,946 & 4 & 14.1 & 81.2 \\
\hline
\end{tabular}

HDI = human development index, PD = population density (inhab $/ \mathrm{km} 2), \mathrm{TNI}=$ Total National Income, DI = Doctors per inhabitant, TS = time at school (year), LE = life expectancy (year). Source: Authors.

The implications of inadequate financial protection for low-paid workers are most evident in countries with higher extreme poverty levels, such as India. In recent pandemics, such as the Middle East respiratory syndrome, doctors were vectors of disease transmission due to inadequate testing and personal protective equipment. With a projected global shortage of 15 million health professionals by 2030, governments have left essential personnel exposed in this time of need (Hoadley et al., 2020).

The uneven response to the pandemic, healthy life expectancy and mortality rates have historically been disproportionate among the wealthiest and most impoverished populations. The effects of COVID-19 have yet to be seen, as the disease begins to spread to the most fragile places, including conflict zones, prisons, and refugee camps. As the global economy deepens into an economic crisis and government rescue programs continue to prioritize industry, scarce resource and funding allocation decisions should aim to reduce inequalities rather than exacerbate them (Bedford et al., 2020)

In the United States, on March 17, 2020, the outbreak had expanded from several isolated groups in Washington, New York, and California to all 50 states and the District of Columbia. On April 2, there were more than 5,000 deaths associated with COVID-19 in the USA. With a global total of more than 1 million cases, the USA is the country with the highest number of reported cases, comprising about a fifth of all infections. Ebola outbreaks in Africa have shown, for example, that when an 
infectious disease hits hospitals, large numbers of people die due to a lack of care for malaria, pneumonia, and other curable diseases, as well as care during pregnancy and childbirth (Peckham, 2020; The Economist, 2020; Anderson et al., 2020). Although job safeguards have recently been enacted in some high-income countries, such as the United Kingdom and the United States, low-income groups do not fully trust these guarantees, as they experience long-standing difficulties in complex benefits systems. On the other hand, many workers (including self-employed workers) can be omitted from such contingency plans (Roser, 2020).

Germany has the third-highest number of Coronavirus cases in Europe, but deaths are relatively few when compared to neighboring countries (April 2020 data), and official statistics showed that 872 deaths by COVID-19 had been reported in Germany in 73522 confirmed cases, which translates into a mortality rate of $1.2 \%$. These findings compare to mortality rates of $11.9 \%$ in Italy, $9 \%$ in Spain, $8.6 \%$ in the Netherlands, $8 \%$ in the United Kingdom, and $7.1 \%$ in France just in the first semester of 2020 (Stafford, 2020; Statista, 2020).

Also, Germany took steps earlier than some other nations to prevent the spread of COVID-19. Initial actions were taken unilaterally by the 16 states of Germany, led by Bavaria (the largest German State and the most affected by COVID-19). In mid-March, states closed schools and most retail businesses, banning meetings and requiring isolation. Those who had COVID-19 or were exposed to it (RKI, 2020) and the vast majority of people in Germany are voluntarily adhering to contact restrictions (Chowell \& Mizumoto, 2020). If patients recovering from COVID-19 are immune to reinfection, the question is not whether Germany has done enough to fight the pandemic, but whether it has taken the right steps (Corman et al., 2019), so Germany is among the best countries with both health and economic actions about the Coronavirus Pandemic to its population. From the authors, it was possible to structure Table 3.

Table 3. WHO requirement and response from Brazil, the USA, and Germany.

\begin{tabular}{cccc}
\hline Requirements & Brazil & USA & Germany \\
\hline Speed in isolation decision & 4.0 & 3.0 & 4.5 \\
Assembly of hospitals and equipment & 3.5 & 4.0 & 4.0 \\
Economic measures for population & 2.0 & 3.0 & 4.5 \\
Organization of States & 2.5 & 3.0 & 4.5 \\
International organization & 2.5 & 2.5 & 4.5 \\
\hline Average & 2.9 & 3.1 & 4.4 \\
\hline
\end{tabular}

Source: Authors.

Although Brazil is considered a more impoverished country than the countries compared (USA and Germany) (Table 3), it has a well-structured public health care service. Other low- and middle-income countries suffer from the pandemic. For example, Nigeria is making difficult decisions as its health system is deficient in dealing with this pandemic.

At the height of the epidemic, Wuhan, China, required 2.6 beds in an intensive care unit (ICU) for every 10,000 adults. Italy has less than half that capacity and is overloaded. However, some low-income countries have only one-hundredth of Italy's infrastructure (one ICU bed per million people), according to Kock et al. (2020). The marks attributed to Brazil with speed in the decision of isolation and Germany, which obtained higher marks about the United States, refer to the government plan of each country that acted quickly to see the consequences experienced by the Chinese. The United States, on the other hand, had a slower response, especially in states like New York, precisely because of the economic chaos that could be caused (Peckham, 2020; The Economist, 2020; Act of Mitigate, 2020; CDC, 2020; Brazil, 2020).

Regarding the assembly of hospitals and equipment, the United States and Germany showed a more efficient infrastructure and economy, and they would have hospital assemblies more quickly. However, the lack of PPE and protective equipment for hospitals was a global problem, regardless of the country's purchasing power. Brazil did not guarantee this quick 
response in setting up hospitals in most states and, therefore, getting a lower score (Brazil, 2020; USA, 2020; Act of Mitigate, 2020; Anderson, 2020).

Economic measures for Germany's population were arranged by plans for companies and by loans and financial protections for populations for the general and low-income population (Act of Mitigate, 2020). In Brazil, the economic plan (Brazil, 2020) started late and with inefficiency and failures for the entire population, and the same happened for the United States, which does not have labor protection, as in Brazil, or a public health system, which ensures free treatment. As such, the country almost had a collapse in health and a significant increase in unemployment insurance claims. In Germany, the country has a whole strategy of supporting legal, economic measures during the pandemic (CDC, 2020; Brazil, 2020; EC, 2020).

States' organization is the most problematic issue between Brazil and the USA due to political issues and disagreements between them. Brazil ranks first on a lesser note, with the head of State of the country and some states insisting on not complying with WHO's social isolation. The United States followed suit with layoffs and a lack of communication between states regarding rapid isolation. On the other hand, Germany was unanimous in complying with WHO rules and abiding by them for the whole country and the entire population (WHO, 2020).

In terms of the international organization, Germany stands out in having a better dialogue with WHO and complying with its laws described following what the institution requires; Brazil and the United States were the most disorganized countries in agreeing with WHO and sanitary measures on closure trade, isolation measures and financial aid for the population (WHO, 2020). Germany stood out with the highest average with high marks in all requirements, following the general WHO standards (2020) and still having plans for fast and efficient isolation for the entire population, financing for the population, and more credibility for the population and internationally, averaging 4.4. Brazil and the United States, respectively, with an average of 2.9 and 3.1, falling short of a rapid response to a pandemic in their countries regarding leadership, economy, and health.

\section{Final Considerations}

While some nations have acted quickly to impose restrictions and recommend social isolation, they are hampered by economic, social, and political factors. Such factors can translate into important repercussions, such as increasing deaths from non-Corona viruses or triggering social violence in populations that lack food and jobs. Through the studied scenarios, Germany considers itself a country with greater stability in the face of a world crisis with more secure legislation and more stable leadership in the face of the problems. Sars-CoV-2 (COVID-19) is the most complex challenge that modern medicine and the world has ever faced. The virus hides, changes form, acts differently on different people, follows paths that are difficult to predict. Through this study of rules and legislation, countries will be able to organize themselves better in the face of a pandemic that is far from over. As an extension of this work, the comparison of the laws in the fight against COVID-19 can be made in relation to developing countries, to the BRICS, and to Latin America, which presented a positive highlight in Uruguay and Chile.

\section{References}

Act to Mitigate the Consequences of the COVID-19 Pandemic under Civil, Insolvency and Criminal Procedure Law. (2020). https://www.bmjv.de/SharedDocs/Gesetzgebungsverfahren/Dokumente/Bgbl_Corona-Pandemie_EN.pdf?_blob=publicationFile\&v=2.

Anderson, R., Heesterbeek, H., Klinkenberg, D. \& Hollingswort T. (2020). How Will country-based mitigation measures influence the course of the COVID19 epidemic? Lancet. 2020 March 6.

Batista A, Antunes B, Faveret G, Peres I, Dantas L, Bastos L, et al. (2020). Dimensionamento de leitos para os casos de infecção por COVID-19 no Estado do Rio de Janeiro para o dia 04 de abril de 2020. Rio de Janeiro: Núcleo de Operações e Inteligência em Saúde.

Bedford. J., Enria, D. \& Giesecke, J., et al. COVID-19: towards controlling of a pandemic. Lancet 2020 ; published online March 17. 
https://doi.org/10.1016/S0140-6736(20)30673-5.

Brasil. (1999). Constituição Federal. Diário Oficial da União. DF, 6, 1999.

Brasil. (2020). Lei n. ${ }^{\circ}$ 13.979, de 6 de fevereiro de 2020. http://www.planalto.gov.br/ccivil_03/_ato2019-2022/2020/lei/L13979.htm.

Castro, M. C., Carvalho, L. R., Chin, T., Kahn, R., Franca, G., Macario, E. M. \& et al. (2020). Demand for hospitalization services for COVID-19 patients in Brazil. MedRxiv 2020, 01 (04).

CDC, Novel. (2020). Coronavirus Pneumonia Emergency Response Epidemiology et al. The epidemiological characteristics of an outbreak of 2019 novel coronavirus diseases (COVID-19) in China. Zhonghua liu xing bing xue za zhi= Zhonghua liuxingbingxue zazhi, 41(2), 145, 2020.

CDC. Center of Disease Control and Prevention (2020). https://www.coronavirus.gov/.

Cheng, P. K., Wong, D. A., Tong, L. K. \& et al. (2004). Viral shedding patterns of coronavirus in patients with probable severe acute respiratory syndrome. Lancet 2004; 363: 1699-700.

Chowell, G. \& Mizumoto, K. (2020). The COVID-19 pandemic in the USA: what might we expect?. The Lancet, 395(10230), 1093-1094.

Corman, V. M., Landt, O., Kaiser, M. \& et al. (2019). Detection of 2019 novel coronavirus (2019-nCoV) by real-time RT-PCR. Euro Surveill 2020;25:pii=2000045.

Direito Penal, saúde pública e epidemia - Parte I. (2020). Jota. https://www.jota.info/opiniao-e-analise/colunas/penal-em-foco/direito-penal-saude-publica-eepidemia-parte-i-15042020.

ECDC. European Centre for Disease Prevention and Control (2020). Resource estimation for contact tracing, quarantine and monitoring activities in the EU/EEA 2020. https://www.ecdc.europa.eu/en/publications-data/resource-estimation-contact-tracing-quarantine-andmonitoring-activities-COVID-19.

EC. European Commission. (2020). COVID-19. 2020 March 1. https://ec.europa.eu/health/coronavirus_en.

FGV. Fundação Getulio Vargas. (2020). Observatório de Política Fiscal - Renda Básica e combate ao COVID-19: A experiência internacional e as propostas em curso. https://observatorio-politica-fiscal.ibre.fgv.br/posts/renda-basica-e-combate-ao-COVID-19-experiencia-internacional-e-propostas-em-curso.

Gordon, J. L. (2019). The role of the State in fostering innovation activity: case studies of the USA and Germany. Brazil. J. Polit. Econ., São Paulo, 39(4), 571-590, https://doi.org/10.1590/0101-31572019-2899.

Hoadley, J., Fuchs, B. \& Lucia, K. (2020). Update on federal surprise billing legislation: new bills contain key differences. https://www. commonwealthfund.org/blog/2020/update-surprise-billing-legislationnew-bills-contain-key-differences.

IHME COVID-19. (2020). Health Service Utilization Forecasting Team; Murray C. Forecasting COVID-19 impact on hospital bed-days, ICU days, ventilator-days and deaths by US state in the next 4 months. https://www.medrxiv.org/content/10.1101/2 020.03.27.20043752v1.

Kock, R. A., Karesh, W. B. \& Veas, F. (2020). 2019-nCoV in context: lessons learned? Lancet Planet Health. https://doi.org/10.1016/S2542-5196(20)300358

Moghadas, S. M., Shoukat, A., Fitzpatrick, M. C., Wells, C. R., Sah, P., Pandey, A. \& et al. (2020). Projecting hospital utilization during the COVID-19 outbreaks in the United States. Proc Natl Acad Sci U S A 2020; 117:9122-6.

National Compensation Survey: Employee Benefits in Private Industry in the United States. (2020). https://www.bls.gov/news.release/pdf/ecec.pdf.

Noronha, K., Guedes, G., Turra, C. M., Andrade, M. V., Botega, L, Nogueira, D \& et al. (2020). Pandemia por COVID-19 em Minas Gerais, Brasil: análise da demanda e da oferta de leitos e equipamentos de ventilação assistida considerando os dife - renciais de estrutura etária, perfil etário de in - fecção, risco etário de internação e distâncias territoriais. São Paulo: Instituto de Estudos para Políticas de Saúde.

Peckham, R. (2020). COVID-19 and the anti-lessons of history. The Lancet, 395(10227), 850-852, 2020.

Pereira, A. S., Shitsuka, D. M., Parreira, F. J., \& Shitsuka, R. (2018). Metodologia da pesquisa científica. UAB/NTE/UFSM. https://repositorio.ufsm.br/bitstream/handle/1/15824/Lic_Computacao_Metodologia-Pesquisa-Cientifica.pdf?sequence=1 .

Rache, B., Nunes, L., Rocha, R., Lago, M., \& Fraga, A. (2020). Como conter a curva no Brasil? Onde a epidemiologia e a economia se encontram. Nota Técnica. Instituto de Estudos para Políticas de Saúde. https://ieps.org.br/pesquisas/como-conter-a-curva-no-brasil-onde-a-epidemiologia-e-a-economia-seencontram/

RKI. Robert Koch Institute. (2020). Current situation report by the Robert Koch Institute on COVID-19. https://www.rki.de/DE/Content/InfAZ/N/Neuartiges_Coronavirus/Situationsberichte/Gesamt.html. (In German and English.).

Roser, M. (2019). The short history of global living conditions and why it matters that we know it. https://ourworldindata. org/a-history-of-global-livingconditions-in-5-charts.

Sarkar, J. \& Chakrabarti, P. (2020). A machine learning model reveals older age and delayed hospitalization as predictors of mortality in patients with COVID-19 (2020) medRxiv.

Stafford, N. (2020). COVID-19: Why Germany's case-fatality rate seems so low. (2020) BMJ, v. 369.

Statista. (2020). Coronavirus (COVID-19) death rate in countries with confirmed deaths and over 1000 reported cases as of April 3, 2020, by country. Apr 2020. 
Research, Society and Development, v. 10, n. 1, e44810111942, 2021

(CC BY 4.0) | ISSN 2525-3409 | DOI: http://dx.doi.org/10.33448/rsd-v10i1.11942

The Economist. (2020). The new coronavirus could have a lasting impact on global supply chains. The Economist. https://www.economist.com/international/2020/02/15/the-new-coronavirus-could-have-a-lasting-impact-on-global-supply-chains.

UNDP. United Nations Development Programme. (2019). http://hdr.undp.org/.

USA. United States Government. (2020). Labor Legislation, 2020. https://www.usa.gov/labor-laws.

Verhagen, M. D., Brazel, D. M., Dowd, J. B., Kashnitsky, I. \& Mills, M. (2020). Predicting peak hospital demand: demographics, spatial variation, and the risk of "hospital deserts" during COVID-19 in England and Wales, 2020. OSFPreprints 2020; March 27.

Waldman, A., Shaw, A., Ngu. A. \& Campbell. S. (2020). Are hospitals near me ready for coronavirus? Here are nine different scenarios. ProPublica.

Walker, P. G. T., Whittaker, C., Watson, O, Baguelin, M., Ainslie, K. E. C., Bhatia, S. \& et al. (2020). The global impact of COVID-19 and strategies for mitigation and suppression. Imperial College of London. https://spiral.imperial.ac.uk:8443/bitstream/10044/1/77735/10/2020-03-26-COVID19-Report-12.pdf. Access in August 2020.

WHO. World Health Organization. (2020). Coronavirus disease (COVID-19) outbreak https://www.who.int/emergencies/diseases/novel-coronavirus-2019.

Whittle, J. \& Hailwood, M. The gender division of labour in early modern England. The Economic History Review, 73(1),3-32.

Zhang, T., McFarlane, K., Vallon, J., Yang, L., Xie, J., Blanchet, J. et al. A model to estimate bed demand for COVID-19 related hospitalization. MedRxiv. 